\title{
Judgement and choice in the 1999 South African election
}

\author{
ROBERT MATTES, HELEN TAYLOR and CHERREL AFRICA*
}

ABSTRACT In this article, we set out the basic points of the theoretical framework of voter choice that underlie the Opinion '99 research project. In contrast to prevailing theories that have characterized voter choice in South Africa as an ethnic or racial census, this approach emphasizes the role of how voters learn about government performance and the alternatives offered by opposition parties. We then deduce a very simplified model that consciously excludes all 'structural' variables and includes only measures of voter evaluations of government performance and views of political parties and candidates. We use discriminant analysis (DA) to predict the partisan preferences of respondents from a nationally representative September 1998 survey with these measures. We find that the partisan choices of a very large majority of South Africans can be correctly predicted with this model.

If people are to govern themselves in any meaningful way, they must be able to control their elected representatives and make government respond to their wishes. Periodic elections provide the most basic and accessible way in which citizens can accomplish this. But for elections to act as a vehicle of popular control over the day-to-day actions of government, citizens must be willing and able to base their vote on whether they are satisfied with what government is doing. They must also be ready to change their vote. Without the threat of losing or gaining votes, and thus losing or winning, governments and opposition parties have no incentive to anticipate the reactions of public opinion to what they do, and the prospects of popular self-government diminish rapidly.

Against these imperatives, one could conclude that democracy in South Africa faces a bleak future if one were to judge by the weight of scholarly opinion. Prominent analysts of South African politics worry about South Africa sliding towards a one-party dominant pattern in which most voters are deeply committed to political parties, where there is no 'undecided middle', and thus little or no prospect for electorally induced change in government.'

One underlying reason for these worries is the post-colonial, or more modestly, newly independent nature of South African society. In such societies, especially in Africa, it is argued that liberation parties who win first elections continue to win re-election from increasingly large majorities. Opposition parties 
become demoralized largely because voters do not vote on the basis of issues, performance or governance, but rather flock to the dominant party to get patronage or because of sheer bandwagoning. ${ }^{2}$

Another factor underlying these fears is the deeply divided nature of South Africa's society. In a widely influential book, Ethnic Groups in Conflict, Donald Horowitz has characterized elections in deeply divided societies as ethnic censuses. ${ }^{3}$ In these societies, elections are the result of 'ascriptive voting'; voting determined by (or at least largely shaped by) birth or descent, rather than by a conscious consideration of party programmes or incumbent performance. Voters do not register choice, but identity. They 'choose, in effect, not to choose but to give their vote predictably on an ethnic basis to an ethnically defined party'. Because, ethnic voters 'put voters of the other group who do choose among parties at a collective disadvantage', ethnic votes tend to drive out non-ethnic votes. ${ }^{4}$ Horowitz's 'census' analogy has had a powerful influence on analysts of divided societies, as well as on many politicians within those societies. This has certainly been true of South Africa where a wide range of domestic political analysts, as well as prominent visiting observers such as Giovanni Sartori, have explained the results of its historic founding 1994 election as an 'ethnic' or a 'racial census'.

South African analysts have pointed to aggregate voting results, as well as previous and ensuing opinion polls to argue that voters in South Africa are driven largely by either the desire to express national or communal liberation and independence, or to display communal solidity with political parties seen to represent that community, or by the fear of communal pressure and intolerance-or some combination of all three. ${ }^{6}$ The clear implication is that communal interests or pressures supersede other voter concerns, so much so that voters may actually vote against their interests, opinions or preferences, or at least irrespective of them. Election events become elections only in the most formal sense. Election results reflect demographic distributions, or ethnic or racial censuses, rather than popular preferences.

While the 'census' image may provide a useful description of elections in divided societies, as an explanation of individual voting behaviour the census theory suffers from a range of methodological and theoretical problems. ${ }^{7}$ Nonetheless, one cannot deny the clear and unmistakable relationship between race and ethnicity and voting patterns in South Africa's national and local elections thus far. The key question is, however, how we interpret these correlations. Quite simply, correlation does not equal causation. There is no necessary relationship between the size of the correlation between ethnicity and the vote and the existence or absence of ethnically motivated voting. Identifying the covariance of demographic factors with voting patterns does not constitute a satisfactory social scientific explanation of individual behaviour and motivation. As Christopher Achen has argued, correlations between demographic factors and the vote do not explain the vote; rather they themselves need to be explained. Instead, we need to ask, 'what is it about a given demographic factor that makes different voters vote differently?'8 
A more satisfactory understanding of how South Africans vote requires us to focus on voters, their motivations, their preferences, how they learn and how they reason. To be sure, we also need to take into account how voter reasoning may be affected by the environment and context in which they find themselves. It also requires collecting appropriate data with which to operationalize and test such a theory. This was the approach underlying the Opinion ' 99 project, an election research consortium of the Institute for Democracy in South Africa (Idasa), the Electoral Institute of South Africa (EISA), Markinor, and the South African Broadcasting Corporation. ${ }^{9}$ In this article, we lay out that theoretical approach and test some very initial, simple deductions of this approach with survey data collected by Opinion ' 99 in the recent election campaign.

\section{Reasoning, information and partisan choice}

We proceed from the assumption that voters support parties and candidates who they think will govern best in the future. ${ }^{10}$ In order to figure out which party can best do this, voters use information. Many analysts will immediately point to citizens' low levels of information about politics and government. However, 'information' means not only factual, textbook information but also much more general knowledge and understanding of what has happened, how things are going, and what is responsible for how things are going. While voters may not be very well informed, this does not mean that they do not reason. All that is meant by a reasoning voter is that, in Achen's words:

Voters do not ignore the information they have, do not fabricate information they do not have, and do not choose what they do not want. Thus, the voters need be neither geniuses nor saints. They are required only to do the best with the information they have."

South Africans do not have to be avid readers of Business Day, or regularly listen to 'PM Live' in order to become informed. They can use whatever information is available to them, and where there is no information, either draw inferences from what they do know, or look to the views of other people or sources whom they think do know, what Samuel Popkin calls 'low information reasoning'. ${ }^{12}$ And one key source of information is the past behaviour (or 'track record') of a government, political party or candidate. In fact, information about what candidates and parties have done in the past is often a better and more reliable guide to how they will behave in the future than what they promise they will do.

For governing parties, the track record of the current administration is extremely important. Voters can reach some sort of summary judgement about how things have been going, and the reasons why, and use that to draw conclusions about how things will go in the future. In order to figure this out, voters are able to get a great deal of relevant information about these things from everyday life. As consumers, people know whether prices are going up or down, and whether salaries are keeping up. If they buy anything on hire-purchase, credit, or own a home, they know something about interest rates. As taxpayers, 
they know whether the government is taking more taxes this year than last, and whether the standard of public services has improved or deteriorated. As workers, they have some idea whether jobs are more or less secure than they were the previous year. By just looking around, they can also know many things about the conditions of the neighbourhood and streets, and whether more or fewer houses appear to be going up. ${ }^{13}$

Yet it is also important to note that people are not simple 'Pocketbook Voters'. To the extent that they base their assessment of government performance on the economy, they tend to look to the larger economy of the community, province, or nation, not to whether they are personally better or worse off. ${ }^{14}$ This is because it is difficult to isolate the government's responsibility for your own personal fortunes separately from what you know about all the other relevant factors. You may have lost your job because of government cutbacks, or mismanagement of the economy, but you may also have lost it because of bad decisions by management, because the boss does not like you, because you took a job that you were not good at, or just plain bad luck. ${ }^{15}$ In contrast, it is much easier to blame or reward the government when you look around and see many of your friends or neighbours being retrenched, or see lots of new houses going up, or see new construction projects hiring workers.

Opposition parties also have track records. What did they do the last time they were in government? What have they done while out of power in terms of representing you, articulating your interests, or exposing government failures? Even if voters have little other information about a candidate or a party, they still may be able to work out several things on the basis of a little knowledge of past history. Knowing whether a candidate was in the military, or police, for example, might give some insight into whether they are likely to be 'tough on crime'. Knowing where they stood in the struggle against apartheid, for example, can also help a voter figure out where that party stands today.

Voters can also look to the style in which candidates and parties campaign. Do they speak with authority? Do they appear to know what they are talking about? Do they seem trustworthy? Do they demonstrate any connection with the voters? Where do they campaign: in city centres, suburbs, townships or squatter camps? Voters can also learn from the things that candidates and parties say, the stances that they take, and the promises that they make during an election campaign (what one might call the 'substance' of the campaign). A final important source of information voters can use to reason who might govern best, is simple demographics. Given no other information about a candidate or a party, a voter can look at things like skin colour, ethnic features, language, accent or even the way a candidate dresses to infer whether it is likely that the candidate, or their party, knows anything, or cares about his or her problems or the problems of their community.

\section{Reasoning in context}

How and where voters get information matters. Group-based voting differences 
do not arise or endure because people are simply a product of their background, or because they simply do what their group or community tells them to do. Rather, since the first voting studies, we have known that voters' perceptions are shaped by the social context in which they receive, filter and interpret information. ${ }^{16}$ People understand politics by asking how a given government, policy, or issue is likely to affect them and people like them. They answer this question, not in isolation, but by speaking to family, neighbours or friends, and by listening to political parties and the news media engage in the crucial process of taking credit and laying blame. People interpret and understand what they know or hear about government and political parties through the 'lenses' of their present circumstances, and through the eyes of the news media and of those they work with, live next to, or socialize with (what social scientists call 'information networks'). ${ }^{17}$

Given the plethora of things that come over the news everyday, we need ways to simplify political reality. Thus, the opinions of trusted sources of information become a valuable 'cue' on issues that we do not know about, or a template against which to test our opinions when we do have some information. These respected sources or 'cues' might range anywhere from a specific magazine, newspaper, television or radio station, or specific writer or correspondent, a community leader, or a respected or knowledgeable friend. Thus, the 'reality' we comprehend, and our interpretation of its consequences for us, may differ radically depending upon our present economic and material circumstances, and where we get our information about politics.

This provides an important clue as to why voting patterns differ so much in South Africa along lines of race, class, and in a few areas, by language and rural/urban distinctions. One of the many effects of the Group Areas Act is that the information networks of vast majorities of black, white, coloured or Indian voters have been contained for the greatest part wholly within particular cultural milieux, each of which was fairly internally consistent with few cross-pressures. Thus, voters' information about their interests and past events (such as apartheid, the struggle against apartheid, the repeal of apartheid, the transition to democracy, and the first five years of democratic government and delivery) is likely to have been received through screens, or informational gatekeepers which ran parallel to race. Thus, voters from different racial groups and different ethnic communities are likely to have literally seen starkly different political worlds when they began to think about the 1999 election.

\section{Partisan identification}

If there is one thing that we have learned in the past 30 years of election research it is that most voters do not make up their minds anew in each election, nor do they make up their minds only when they enter the election booth, or in the last few days of an election campaign. Most voters tend to have pre-existing predispositions about which party they 'identify with' or feel close to, predispositions that underlie the actual voting choice. 
Voting scholars originally saw party identification as a largely unchanging attitude based almost solely on socialization from parents and peers, from which voters could deviate or 'defect' from in a given election, but usually return to in the long run. ${ }^{18}$ Now, however we know that party identification is better characterized as a voters' 'standing decision' that is constantly updated based on a voter's evolving evaluations of political parties, leaders and performance. ${ }^{19}$

At the age of 18, the best sources of such information may indeed be one's parents or peers. However, the original decision is constantly updated by new information, information gleaned from observing economic trends visible in everyday life, from the news media, or from respected friends and colleagues. ${ }^{20}$ As voters accumulate experience with parties and government, their partisan identification may change. If their party seems to continue to perform well and 'deliver the goods' (whether as government or in the role of an opposition expressing your political values and interests), and if you see no better alternative, you will stick with that party and may even develop a stronger identification with it. But if your initial loyalties are disappointed, if a party does not perform well, your loyalties will weaken. If you see a better alternative, you may switch your loyalties and develop a different partisan identification.

Voters whose experiences have led them to adopt such a 'standing decision' and identify with a party are much more likely to vote on election day, and are very likely to vote for that party. These 'independent voters', potentially, are more open to persuasion in the election campaign and may base their choice on party stances on the key issues of the day, as well as how leaders and parties campaign. At the same time, we know that political parties have to work harder to get independent voters to come out and vote.

\section{Theoretical expectations}

What does all this mean for an analysis of voting in the 1999 South African election? Here, we sketch out broadly a simple model and test it with survey data from a September 1998 nationally representative survey of 2,200 eligible voters conducted by Opinion ' 99 .

As a first point of departure, as voters moved closer to the forthcoming 1999 election, their evolving partisan identification (or lack thereof) should have been a clear reflection of their understandings of what had gone on in the first four years of democratic government. Principally, this would involve an assessment of the track record of the governing party, the ANC. In reasoning about this track record, voters could be expected to have looked primarily to their understanding of general national economic trends, as well as developments in other more specific areas, such as employment prospects, housing and crime. These should have then enabled voters to form a general assessment of how government was performing, an assessment that should be directly related to their current partisan stances.

Satisfaction with these trends should help the ANC retain the loyalties of its support base as well as attract new supporters. While dissatisfaction should have 
led voters away from the ANC, it would not tell us which opposition party such voters would move toward, if any.

Those who did not identify with the governing party needed to look to other types of evaluations in order to decide which opposition party, if any, they might move toward. As argued above, one important source of information were the track records of opposition parties: how had they performed as parties, and had they convinced voters dissatisfied with government performance that they offered a viable alternative? Those who were dissatisfied with government performance yet who did not see any alternative among the opposition parties should be independent. When it comes to deciding who to vote for those who identify with a party would be expected to be likely to go out and vote, and very likely to vote for that party. Those who are independent will be less likely to vote, but those that do will be much more likely to base their vote on 'short-term forces' such as evaluations of the party's main candidates and a consideration of how the parties stand on the issues, especially those issues that the independent voter sees of primary importance.

\section{Empirical analysis}

Whilst a full and conclusive analysis of the data collected by Opinion '99 lies outside of the scope of this article, here we present as simple a model as possible: a model which also presents a critical test of the approach underlying the Opinion '99 project, and conversely, of alternative explanations of voting that emphasize the dominant role of race or ethnicity. Our model consciously puts as great a weight as possible on voters' evaluations and preferences, and as little as possible on structural and demographic variables. To what extent can we statistically account for people's partisan choices (both their partisan identification as well as their vote choice in a simulated secret election) solely by reference to their evaluations of national trends, of government performance, party performance and images, party leaders and issues?

To do this, we use a statistical test called discriminant analysis (DA). DA is useful to perform multivariate analysis when the dependent variable consists of a series of unordered, discrete outcomes, such as party identification or vote choice. DA helps us understand whether and how a series of explanatory variables (in this case, voters' evaluations) effectively discriminates cases (voters) into the various categories of the dependent variable (supporting or voting for various parties).

DA does this first, by calculating a set of functions that help discriminate cases between the categories of the dependent variable and determining the relative strength of the independent variables in the process. Second, DA uses these discriminant functions to predict the group membership of each case. The rate at which it can assign cases into their correct categories (e.g. political party support) tells us how powerful the independent variables are in discriminating cases among various categories. We restrict discussion of the following analysis to this second step. And here we develop three equations and apply them to three 
different groups of survey respondents to test the intentionally simplified model we have described above.

\section{Equation 1 (to support the ANC or not)}

First of all, we look among all survey respondents and attempt to assess the degree to which voter assessments of the economy and government performance can help us predict whether a voter would identify with the ANC or not. In the September 1998 survey, Opinion '99 found that 35 per cent of all respondents identified with the ANC (and thus 65 per cent either identified with an opposition party or were independent).

Altogether 18 individual variables were entered into the equation measuring voter assessments of national economic conditions (3), the overall direction of the country (1), and assessments of general (3) and specific (11) areas of government performance. In a sense, these variables characterize a fairly comprehensive referendum on the first five years of democratic government. The dependent variable of party identification was re-coded as ANC/non-ANC.

Overall, these variables correctly predicts the ANC/non-ANC stance of 77 per cent of all respondents. Of those who told us they identified with the ANC, the model correctly placed 77 per cent as ANC. It also correctly classified 83 per cent of those who did not identify with the ANC. There are no absolute standards by which to judge the classificatory power of a DA equation. The only useful evaluation is to consider that this is a substantial improvement in predictive power over a purely random classification (which, with two categories, would have a success rate of 50 per cent). When applied to the fully specified party identification variable (e.g. one with all partisan categories), this equation successfully classifies 70 per cent of all ANC identifiers, but very low proportions of other opposition party identifiers. This confirms that a referendum on the past allows people to decide whether or not to support the government, but not which opposition party to support or whether to support one. Thus, we are able to predict successfully the partisan (ANC/non-ANC) tendencies of 77 per cent of voters based on no more than knowledge of their evaluations of national trends and government performance (see Table 1).

\section{Equation 2 (looking at the alternatives)}

Second, we look among only those survey respondents who do not identify with the ANC (65 per cent of the total sample), to assess the extent to which assessments of past performance of the opposition parties help account for which opposition parties they supported or whether they identified with one at all.

We used a set of variables measuring voters' assessments of selected specific actions of political parties since 1994 (21), of how parties had been performing their functions as parties (7), and whether they felt parties were representative (7), believable (7), trustworthy (7) and competent to govern if they were elected 
Table 1. Successful classification rates for the three equations

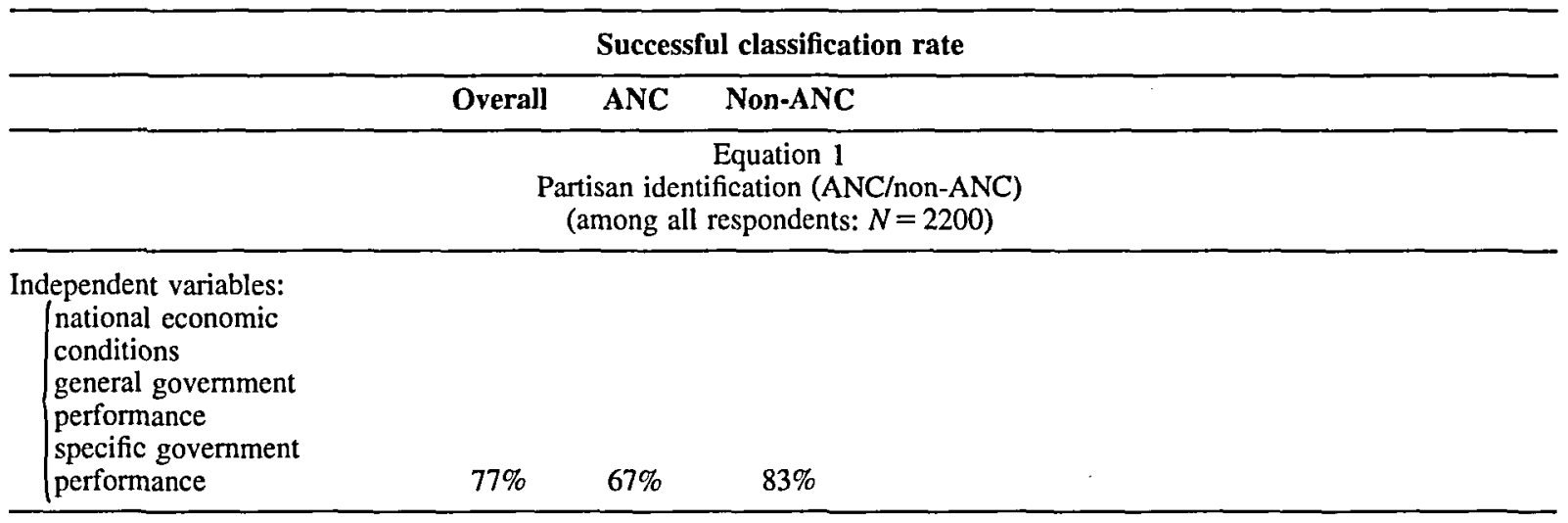

\section{Equation 2}

Dependent variable: partisan identification

(among independents and non-ANC identifiers: $N=1430$ )

\begin{tabular}{|c|c|c|c|c|c|c|c|c|}
\hline $\begin{array}{l}\text { Independent variables: } \\
\qquad \begin{array}{l}\text { general party performance } \\
\text { specific party performance } \\
\text { party credibility } \\
\text { party inclusiveness } \\
\text { party trustworthiness } \\
\text { party competence }\end{array}\end{array}$ & Overall & ANC & $\mathbf{D P}$ & IFP & NNP & UDM & PAC & Ind. \\
\hline
\end{tabular}

Equation 3

Dependent variable: national vote choice in a simulated secret ballot (among independents: $N=990$ )

\begin{tabular}{|c|c|c|c|c|c|c|c|c|}
\hline $\begin{array}{l}\text { Party leader ratings } \\
\qquad\left\{\begin{array}{l}\text { party able to address most } \\
\text { important problem }\end{array}\right.\end{array}$ & $\begin{array}{l}\text { Overall } \\
60 \%\end{array}$ & $\begin{array}{l}\text { ANC } \\
73 \%\end{array}$ & $\begin{array}{l}\text { DP } \\
56 \%\end{array}$ & $\begin{array}{l}\text { IFP } \\
47 \%\end{array}$ & $\begin{array}{l}\text { NNP } \\
56 \%\end{array}$ & $\begin{array}{l}\text { UDM } \\
44 \%\end{array}$ & $\begin{array}{l}\text { PAC } \\
31 \%\end{array}$ & $\begin{array}{c}\text { Undecided/ } \\
\text { undisclosed } \\
55 \%\end{array}$ \\
\hline
\end{tabular}


(7). Each set of questions was asked about the seven largest parties at that point (ANC, NNP, DP, IFP, FF, UDM, PAC).

The variation in how people assess these political parties successfully predicts the partisan preference (or lack thereof) of 88 per cent of all non-ANCsupporting respondents; 93 per cent of all independent respondents were correctly classified as such (see Table 1). To put this in context, random assignment of cases to the party identification variable with 14 categories would have had an overall success rate of only 7 per cent.

\section{Equation 3 (deciding who to vote for)}

Finally, we make a simple assumption that those voters who identified with a particular political party would choose to vote for it. Our area of interest is, thus, those voters who did not yet identify with a political party ( 45 per cent). To what degree can candidate evaluations, and assessments of which parties are best able to address voters' most important issues, account for these respondents vote in a simulated secret ballot?

Thus, we entered seven variables that measured respondents' ratings of each of the main parties' leaders and eight dummy variables for each party (coded 0 or 1) that measured whether a voter felt that that party (or no party) could best address what they felt was the most important issue facing the country.

It is important to remember that the election campaign had not yet started in earnest in September 1998 and thus independent voters should not have begun to focus on candidates and issues to the extent that they might have by May 1999. Nonetheless, these variables could help successfully predict the national vote (including whether the respondent was still undecided) of 60 per cent of independent respondents. A totally random classification would have a success rate of 7 per cent (see Table 1).

\section{Discussion}

We firmly recognize that the assumptions we have made above are extremely simplistic. Nonetheless this very simplified model of partisan preference formation also offers a heuristic, critical test of the common wisdom about the role of structural factors such as race, ethnicity and class. We have fully acknowledged in the theoretical observations at the beginning of this article that such structural factors do play important moderating (though by no means determining) roles in shaping what people know and what they think about politics. Yet given South African political analysts' continuing emphasis on these factors, it is worthwhile to test a model that consciously excludes all of these factors.

The simple and fundamental finding is that with absolutely no knowledge of voters' race, language, or class, we have been able to predict successfully the partisan tendencies of the vast majority of survey respondents, based on no more than their evaluations of political performance and economic trends.

To this, those who emphasize the role of ethnicity and race as determinants 
of voting might respond that the success of this model is simply due to the fact that different racial or ethnic groups supported different parties, and that each group also had consistent, communally determined evaluations of the political system that are the consequence of, rather than the cause of, partisan support. While there could be many responses to this argument, one simple fact will suffice. It is true that ANC support correlates with a more positive view of the first five years. It is also true that African voters were much more likely to have positive views than other voters. However, at the time of this survey in September 1998, while Africans were more optimistic about the direction of the country (to take one major example), only 53 per cent felt the country was headed in the right direction. One-third of all African voters felt it was going in the wrong direction. And, at that time, only slightly more than one-half of all African voters identified with the ANC.

The effect of different communal, cultural or economic contexts on political behaviour is probabilistic, not determinist. Living in a certain neighbourhood, going to a certain school or church, having a certain level of income or type of job, and using specific types of news media will all tend to shape how one perceives political and economic developments, but it certainly does not determine it.

Even this extremely simplified model demonstrates strong empirical support for the application to the South African electorate of the theoretical framework that informed the Opinion ' 99 project; a framework that weaves together the most important findings of three themes of international voting research: the Columbia or 'sociological' approach of Lazarfeld and Berelson, the Michigan or 'social-psychological' approach of Angus Campbell and his colleagues, as well as the economic or rationalist approach of Downs, Key and Popkin. Thus while South Africa may indeed be a deeply divided society, we do not need to resort to particularized theories of dominant party systems, or of post-colonial or ethnically divided societies to understand the major forces that account for voter behaviour in this country.

When South African voters decide which political parties to entrust with their future, they look to real-world events (or at least at those events so perceived) such as the overall direction of the country and the economy, government performance, opposition parties, candidates and key issues. Thus political performance matters, and election campaigns matter. Race, class and ethnicity, and the interactions among them, certainly shape how voters perceive performance and campaigns. But it may be surprising to some to see just how much we can understand about voters in this country before we even take account of the socializing effects of culture, neighbourhood, workplace, living standards or news media.

These findings focus our attention on three broad dynamics that shaped the 1999 election: (1) the relatively strong public approval of the ANC's record of performance and delivery in the first five years; (2) the fact that the ANC ran a very strong election campaign that further increased these positive evaluations in the last four months before the election; and (3) the tremendous obstacles that 
confront opposition parties in convincing voters to take them as a real alternative.

South Africa may indeed face the very real prospect of rigidified party cleavages which will reify the present partisan configuration, and ensure sustained party dominance. However, in contrast to the usual interpretations, this prospect is not the result of an electorate filled with ethnically or racially motivated voters blind to performance of government and political parties, or their own material interests. Rather, in an extremely racially and economically stratified society, voters are doing the best they can with what they know (or at least what they think they know) about how political parties and government performance affects their interests. If partisan cleavages fail to realign over time, it will be the result of party leaders' failure to grapple with this basic fact and to find ways to change what voters know, and how voters perceive them. It will not be the result of voters being too stubborn to change themselves.

\section{Notes and references}

* Robert Mattes is Manager of Idasa's Public Opinion Service based in Cape Town. Helen Taylor and Cherrel Africa are both Senior Researchers with the Public Opinion Service. We would like to thank Rajen Govender for his advice and comments. Any errors in analysis or interpretation, however, are the authors alone.

1. Hermann Giliomee and Charles Simkins (eds) (1990) The Awkward Embrace: One-Party Domination and Democracy (Cape Town: Tafelberg); Hermann Giliomee (1998) 'South Africa's Emerging Dominant Party Regime', Journal of Democracy, 9 (4), pp. 124-42.

2. Lawrence Schlemmer (1998) 'Where the Parties Stand Now', Focus, 10, pp. 25-8.

3. Donald Horowitz (1985) Ethnic Groups in Conflict (Berkeley: University of California Press); Donald Horowitz (1991) A Democratic South Africa? Constitutional Engineering in a Divided Society (Cape Town: Oxford University Press). See also Alvin Rabushka and Kenneth Shepsle (1972) Politics in Plural Societies: A Theory of Political Instability (Columbus, Oh.: Charles Merrill); Arend Lijphart (1978) Democracy in Plural Societies (New Haven: Yale University Press).

4. Donald Horowitz (1985), op. cit., pp. 319-24 and p. 346.

5. Lawrence Schlemmer (1994) 'South Africa's First Open Election and the Future of its New Democracy', in Hermann Giliomee and Lawrence Schlemmer (eds), The Bold Experiment: South Africa's New Democracy (Halfway House: Southern); Hermann Giliomee (1994) 'The National Party's Campaign for a Liberation Election', David Welsh (1994) 'The Democratic Party' and Andrew Reynolds (1994) 'The Results', all in Andrew Reynolds (ed.), Election '94 South Africa: The Campaigns, Results and Future Prospects (Cape Town: David Philip); R.W. Johnson (1996) 'The 1994 Election: Outcome and Analysis', in R.W. Johnson and Lawrence Schlemmer (eds), Launching Democracy: South Africa's First Open Election (New Haven: Yale University Press); and Giovanni Sartori, 'Constitutional Court needs Minorities to Protect Democracy', Business Day, 2 August 1995, p. 8.

6. Lawrence Schlemmer (1992) 'In the Shadow of the Past', Indicator SA, 9 (4), pp. 13-14; Roger Southall (1994) 'South Africa's 1994 Election in an African Perspective', African Insight, 24 (2), pp. 86-98; David Welsh (1995) 'Opposition or Coalition? Implications for the Consolidation of Democracy in South Africa', in Hennie Kotzé (ed.) Parliamentary Dynamics (Stellenbosch: University of Stellenbosch); Johnson and Schlemmer (eds) (1996), op. cit.

7. For a detailed theoretical critique, see Robert Mattes and Amanda Gouws (1998) 'Race, Ethnicity and Voting Behavior: Lessons from South Africa', in Timothy Sisk and Andrew Reynolds (eds), Elections and Conflict Management in Africa (Washington DC: United States Institute of Peace Press).

8. Christopher Achen (1992) 'Social Psychology, Demographic Variables and the Linear Regression: Breaking the Iron Triangle in Voter Research', Political Behavior, 14 (3), p. 206, p. 209.

9. We would like to thank the Government of Ireland for a grant to Idasa and EISA that made this project possible. We would also like to thank Anneke Greyling and Mari Harris of Markinor for their invaluable efforts and expertise during this project. 
10. Samuel Popkin (1994) The Reasoning Voter: Communications and Persuasion In Presidential Campaigns (Chicago: University of Chicago Press).

11. Achen (1992), op. cit., p. 198.

12. Popkin (1994), op. cit.

13. lbid.

14. Donald Kinder and Broderick Kiewet (1981) 'Sociotropic Politics: The American Case', British Journal of Political Science, 11, pp. 129-161.

15. Lee Sigelman, Carol K. Sigelman and David Bullock (1991) 'Reconsidering Pocketbook Voting: An Experimental Approach', Political Behavior, 13 (2), pp. 129-149.

16. Paul Lazarfeld, Bernard Berelson and Hazel Gaudet (1948) The People's Choice (New York: Columbia University Press); and Berelson, Lazarfeld and William McPhee (1954) Voting: A Study of Opinion Formation during a Presidential Campaign (Chicago: University of Chicago Press).

17. Robert Huckfeldt and John Sprague (1987) 'Networks in Context: The Social Flow of Political Information', American Political Science Review, 81, pp. 1197-213.

18. Angus Campbell, Philip Converse, Donald Stokes and Warren Miller (1960) The American Voter (New York: John Wiley).

19. V.O. Key (1967) The Responsible Electorate: Rationality in Presidential Voting, 1936-1960 (Cambridge: Harvard University Press); Morris Fiorina (1979) Retrospective Voting in American Presidential Elections (New Haven: Yale University Press); Achen (1992), op. cit; Popkin (1994), op. cit.

20. Achen (1992), op cit. 